\title{
Introduction
}

\section{MARIUSZ BARANOWSKI*}

Adam Mickiewicz University in Poznań, Poland ORCID 0000-0001-6755-9368

\section{ANNA ODROWĄŻ-COATES}

The Maria Grzegorzewska University, Poland

ORCID 0000-0002-2112-8711

\section{ATTEMPTING TO REGISTER CHANGES: THE EDUCATIONAL DIMENTION OF CONTEMPORARY SOCIETIES}

When registering the changes affecting our societies, which undoubtedly have a multidimensional character and occur at different speeds, it is impossible to disregard the issue of education. This is especially true in the context of the discourse focusing on so-called cognitive capitalism, creative industries, intangible work, gig/sharing economy, education is an extremely important element of not only "the personal troubles", but also "the public issues of social structure", to use C. Wright Mills (2000: 8) terms.

Particularly in times of multidimensional changes in educational institutions in developed countries and those which, according to some, are supposed to follow their path, it is worthwhile to take up this subject and describe good models of the egalitarian education system, as well as, on the other hand, to publicise the attempts to dismantle this system and limit its autonomy. In the context of recent threats, it is worth remembering Stuart Hall's warning that "[ $t]$ he University is a critical institution or it is nothing" (Giroux 2016:3). The independence of university community

* Corresponding author: Adam Mickiewicz University in Poznań, Institute of Sociology, Szamarzewskiego 89 C, 60-568 Poznań, Poland.

E-mail: mariusz.baranowski@amu.edu.pl 
is of value despite the hierarchical structure of such institutions, which repeatedly contradicts the ideals of democratisation of social life. The same could be said of the limited possibilities for political intervention in the core curriculum in primary and secondary schools. While criticizing existing solutions in the field of education, we should continue our efforts to defend them against external political and economic influences, because both tendencies deprive society (understood collectively, and not as a set of egoistic individuals) of the foundations of criticism and of the capacity for opposing anti-social practices (see Czapnik 2017, 2016).

In order to appreciate how important connections are in the quest for obtaining a proper education, it is illustrative to have a look at the example of a well-known sociologist - Richard Sennett (privately the husband of the equally famous Saskia Sassen). In his book Respect in a World of Inequality, the famous American sociologist explained the circumstances in which he, an injured young cellist, became a student of Harvard:

I myself [said Sennett (2012: 34) - M.B.] managed to escape the war thanks to the help of sociologist David Riesman. His older daughter met me with him. We always got along very well because he liked to listen and I liked to talk. Having heard about my problems, he accepted me at Harvard.

Along these lines, one would have to believe Harvard at that time was an ordinary academic centre, that every injured would-be musician, volleyball or basketball player could get an offer to study at MIT, Stanford or Harvard. Such a trajectory of fate seems specifically American. In the United States, inequalities in the access to best universities are class-conditioned, and tendencies to commodify higher education are an unrivalled blueprint for European countries.

The very division of universities into public and private (see Baranowski 2011) is not a sufficient justification for deep educational inequalities, which have measurable consequences when it comes to interests of particular social categories (or, to use the term Max Weber - in the dimension of realising life chances). This makes it all the more important to appreciate social efforts to enforce - obviously limited - democratisation of access to education systems at all levels, which took place in the past and must be applied nowadays. On the other hand, as Joseph Stiglitz (2009) pointed out, 
we must be aware that:

The elites of nineteenth-century countries that extended education must have known that there was a risk that this would over the long run weaken their dominance of the political franchise; yet the short-term economic advantages of having a more educated workplace seem to have dominated the long-term political consequences.

While recognising the contribution of universal public education (in particular to the quality of life of society and to the empowerment of democratic institutions), it is worth contemplating differentiated approaches to education. In this issue one will find articles analyzing different approaches to the topic at hand, and more importantly - discussed in different cultural contexts (Mexico, Brazil, Poland), which are often overlooked in mainstream journals focusing on the countries of the capitalist core (see Wallerstein 2004).

When reading the articles included in this issue, it is worth remembering Pierre Bourdieu's remark, which in An Invitation to Reflexive Sociology stated:

When the dominant manage to crush and annul the resistance and the reactions of the dominated, when all movements go exclusively from the top down, the effects of domination are such that the struggle and the dialectic that are constitutive of the field cease. There is history only as long as people revolt, resist, act. Total institutions - asylums, prisons, concentration camps - or dictatorial states are attempts to institute an end to history (Bourdieu, Wacquant 1992:102).

Addressing such educational problems from the perspective of subtle exclusion mechanisms (see Odrowąż-Coates, Goswami 2017), the approach of inspiring education theorists and practitioners (Janusz Korczak), or the explication of national contexts of teaching systems and language issues are manifestations of a history. And since history is still going on in spite of famous appeals for its end (Fukuyama 1992), the situation cannot be completely hopeless. 
Thus, we invite you to read all articles and reviews, as well as an interview with Prof. Norman Davies.

\section{REFERENCES}

Baranowski, Mariusz. 2011. "The Property Rights Theory Approach from a Socio-Economic Viewpoint." Studia Historiae Oeconomicae 28-29:3-16.

Bourdieu, Pierre and Loic J. D. Wacquant. 1992. An Invitation to Reflexive Sociology. Cambridge: Polity Press.

Czapnik, Sławomir. 2016. "Jak słowo ciałem uczynić. Z Zygmuntem Baumanem rozmawia Sławomir Czapnik." Studia Krytyczne 2: 8-20.

Czapnik, Sławomir. 2017. "An Interview with Zygmunt Bauman: How to Turn the Word into Flesh." Theory, Culture \& Society 34(4): 115-129. DOI: $10.1177 / 0263276417715312$

Fukuyama, Francis. 1992. The End of History and the Last Man. New York: The Free Press.

Giroux, Henry A. 2016. "Writing the Public Good Back into Education: Reclaiming the Role of the Public Intellectual." Pp. 3-28 in The New Public Intellectual. Politics, Theory, and the Public Sphere, edited by J. R. Di Leo and P. Hitchcock. London: Palgrave Macmillan.

Mills, C. Wright. 2000. The Sociological Imagination (With a new Afterword by Todd Gitlin). Oxfrod, New York: Oxford University Press.

Odrowąż-Coates, Anna and Sribas Goswami, eds. 2017. Symbolic Violence in Socio-Educational Contexts. A Post-Colonial Critique. Warszawa: Wydawnictwo Akademii Pedagogiki Specjalnej.

Sennett, Richard. 2012. Szacunek w świecie nierówności. Warszawa: Warszawskie Wydawnictwo Literackie Muza SA.

Stiglitz, Joseph E. 2012. The Price of Inequality: How Today's Divided Society Endangers Our Future. New York, London: W.W. Norton \& Company.

Wallerstein, Immanuel. 2004. World-Systems Analysis. An Introduction. Durham and London: Duke University Press. 